\title{
United Nations Peacekeeping, Human Rights, and the Protection of Civilians
}

\author{
Ibrabim J. Wani
}

With the increasing trend toward human rights violations and the displacement of civilian populations in conflict, the protection of civilians has become an essential part of peacekeeping. ${ }^{1}$ This trend has been dictated by the changing circumstances of conflict and is supported by the international normative order and global human rights framework. ${ }^{2}$ Drawing on lessons from United Nations (UN)-led peacekeeping operations in Africa, ${ }^{3}$ this chapter discusses the background and evolution of peacekeeping engagement on issues related to human rights and the protection of civilians; the array of norms and institutions that have developed to formalize the mandate in the UN peacekeeping framework; and experiences, lessons, and challenges in its implementation.

Despite some notable achievements, much remains to be done to bridge the gap between rhetoric and concrete actions so that civilians are not, as they all-too-often are, treated as fodder in conflict. ${ }^{4}$ It is

\section{J. Wani $(\bowtie)$}

Former director of the Human Rights Division, UN Mission in the Republic of South Sudan (UNMISS), Juba, South Sudan

T. McNamee and M. Muyangwa (eds.),

The State of Peacebuilding in Africa, https://doi.org/10.1007/978-3-030-46636-7_6 
a challenging and complex undertaking, confronting intractable political problems in countries where communities are deeply fragmented, mechanisms for conflict mediation and resolution are lacking, and state institutions barely functioning. This is sometimes complicated by the fact that the state itself may be an enabler, if not directly complicit, in violence against civilians. At the international level, the protection of civilians also suffers from uncertain political support, conceptual uncertainty, and other inherent contradictions in its normative and political framework. On a positive note, there is growing awareness-evidenced by regular reviews and robust debates - that this important undertaking remains a work in progress. Nevertheless, there is a crucial need for a meaningful dialogue to seek consensus and address the fundamental challenges and internal contradictions highlighted below.

\section{The Basis of the Mandate}

UN peacekeeping engagement with human rights, and the attendant problems of internal displacement and refugees, was in large part compelled by the horrors of the 1990s, particularly the 1994 Rwanda genocide and the massacre of Bosnians a year later at Srebrenica in the former Yugoslavia. Until then, peacekeeping was largely affixed to its original conception as a limited instrument interposed between conflicting parties and playing a rather passive role. The specter of a noticeable international presence watching or, worse, fleeing while hundreds of thousands of helpless civilians were massacred evoked outrage and shame, challenged the credibility and legitimacy of the UN and the global peace and security order, ${ }^{5}$ and triggered critical reviews of peacekeeping. ${ }^{6}$

The result was the pledge to "never again" allow a repeat of such atrocities as Rwanda and Srebrenica and the declaration that the international community had a duty to intervene when such circumstances arose. UN peacekeeping was the obvious instrument of intervention. As the UN Secretary-General noted in his report to the General Assembly at the time,

[t]he plight of civilians is no longer something which can be neglected, or made secondary because it complicates political negotiations or interests. It is fundamental to the central mandate of the Organization. The responsibility for the protection of civilians cannot be transferred to others. The 
United Nations is the only international organization with the reach and authority to end these practices.

Despite these laudable affirmations, civilians continued to suffer gruesome atrocities in conflicts, which, in turn, drew UN peacekeeping into the inevitable undertaking of human rights protection. Recent conflicts in the Central African Republic (CAR), the Democratic Republic of the Congo (DRC), Mali, South Sudan, and Sudan illustrate this trend. Since December 2013, the Security Council has progressively reinforced the mandate of the UN Mission in South Sudan (UNMISS) as the human rights situation has deteriorated. The glimmer of hope that greeted South Sudan's independence in 2011 following more than five decades of conflict soon faded when another round of conflict, one of the most brutal and destructive conflicts of the twenty-first century, flared up in December 2013. The conflict has been characterized by revenge killings, sexual and gender-based violence, the recruitment of child soldiers, the destruction of homes and other personal property, and the forcible displacement of more than half of the country's population.

South Sudan is perhaps an extreme example, but similar phenomena exist where UN peacekeeper are deployed in large numbers. In the CAR, civilians are caught up in the ferocious conflict between the anti-Balaka and Séléka, thousands have been killed and many are displaced within the country and other neighboring countries. The multiple armed groups and government forces in the DRC continuously target civilians, particularly in the eastern part of the country. In Mali, the Jama'at Nusrat al-Islam wal Muslimin (JNIM) and affiliated insurgent groups have continuously attacked and killed civilians, and in Darfur, for more than a decade now, civilians have been targeted and killed or forced into camps for Internally Displaced Persons (IDPs).

The so-called "CNN effect," which projects the horrors of conflict into living rooms around the world in real time, ${ }^{8}$ puts pressure on governments, the UN system, and the international community to do something to halt gross violations of human rights. The presence of a UN peacekeeping operation on the ground has often been the logical and most cost-effective response mechanism. Where no peacekeeping mission existed, the UN was compelled to establish one.

Ironically, the presence of the UN on the ground, in turn, has fostered the expectation that it will provide protection to the civilian population. The failure to fulfill this expectation is perceived as a potentially 
serious blemish on the credibility and legitimacy of the UN and the international system that could undermine its central purpose to facilitate and support a peace process. In other words, UN peacekeeping has become the instrument of last resort in situations of human rights and humanitarian crises. Beyond this practical dimension, UN peacekeeping engagement on human rights and the protection of civilians and refugees is also considered integral and essential to its primary mission and core purpose of securing peace. Systematic human rights violations and the displacement of populations are not only a result of the conflict; experience also shows that they perpetuate conflict. Peace cannot be realized when civilians do not feel secure and safe, and public confidence, which is essential to the realization of sustainable peace and security, cannot exist when civilians are systematically and consistently threatened or abused.

\section{The Normative and Institutional Framework}

In 1999, the United Nations Security Council explicitly mandated the UN Mission in Sierra Leone (UNAMSIL) to "take the necessary action... within its capabilities and areas of deployment, to afford protection to civilians under imminent threat of physical violence." 9 Every UN peacekeeping mission established since then has had an explicit mandate from the Security Council to protect civilians, ${ }^{10}$ (only four out of the fourteen active UN peacekeeping operations do not have the explicit mandate to protect civilians). ${ }^{11}$ An elaborate body of norms, policies, and institutions across the UN system, which includes the UN Charter and the global human rights and humanitarian laws framework, Security Council resolutions and pronouncements, and internal UN policies and guidelines, supports the formalization and operationalization of human rights and the protection of civilians as priorities for UN peacekeeping.

\section{IMPLEMENTATION AND TRACK RECORD}

Nearly 20 years of UN peacekeeping experience with the protection of civilians and human rights, most of it in Africa, has been extensively documented and reviewed. The most recent such review was by the High-Level Independent Panel on United Nations Peace Operations (HIPPO). ${ }^{12}$ While there have been no incidents of the magnitude of the Rwanda genocide-although conflict in South Sudan has been described 
as "genocide" by some- the plight of civilians in conflict has been increasingly brought to the fore through actions by peacekeepers, including when the presence or action by a peacekeeping mission has arguably saved civilians. Overall, however, the experience has been unsatisfactory.

At the political level, the UN Security Council has been more responsive to civilian atrocities and is more likely to deploy a peacekeeping operation when there is widespread violence and systematic human rights violations, as the CAR mission (MINUSCA) illustrates. Enforcement mandates which empower peacekeepers to intervene with armed actors in order to protect civilians are also more common. The Security Council is also frequently engaging on human rights and refugee issues, highlighting their importance in peace and security.

There is some evidence that peacekeeping has reduced the occurrence, duration, and intensity of conflict as well as the likelihood of a resurgence of conflict. ${ }^{13}$ The presence of a peacekeeping force has also been cited as an important deterrent and confidence builder, dissuading attacks against civilians and supporting the settlement of displaced civilians and the return and resettlement of refugees. ${ }^{14}$

In Angola, Côte d'Ivoire, Liberia, Namibia, Mozambique, Sierra Leone, and Liberia, UN peacekeeping made positive contributions to the protection of civilians. Through mediation and assisting reconciliation processes, supporting elections and democratization, helping establish the rule of law, and facilitating the repatriation and resettlement of internally displaced civilians and refugees, tangible improvements were made to the lives of ordinary citizens in these countries.

At the same time, plenty of data suggests that claims of "peacekeeping successes" may be exaggerated. Often much vaunted successes are shortlived, many conflicts tend to relapse, not least because peacekeeping operations typically do not address the underlying issues which gave rise to conflict in the first place. ${ }^{15}$

\section{LESSONS AND CHALlenges}

Extensive reviews of the record of UN peacekeeping the protection of civilians identify several important lessons and challenges. Besides the complexity of the mandate and the difficult environment under which peacekeeping operations are deployed, ${ }^{16}$ key issues include: 
i. The uncertainty of political support for peacekeeping involvement in human rights;

ii. ambiguities surrounding the scope of the mandate; and

iii. lack of coherence and a common understanding around the challenges of multidimensional peacekeeping operations, in particular the problem of overcrowded agendas, resource constraints and limited capabilities and issues related to leadership.

The wide scope of responsibilities and tasks in multidimensional peacekeeping operations has a particular impact on human rights and protection of civilians. In addition to the primary mission of facilitating a peace process, the typical peacekeeping operation is required to support the extension of state authority, capacity building, the rule of law, building a police force, gender integration, child protection, and support to civil society and non-governmental organizations, just to name a few. These are all considered priorities, which means that the protection of civilians and human rights has to compete with dozens of other priorities for attention, political support, and resources. Moreover, the various mandates and tasks require different skills and capabilities and many tend to overlap and are expressed in vague terms, which the different units interpret in different ways. ${ }^{17}$

Budget and resource constraints also have a significant impact on human rights and protection of civilians. There is a legitimate concern about the cost of peacekeeping, which in the last few years has averaged between US \$7-8 billion annually, most of which is borne by about ten countries. High as it is, almost every analysis has pointed out that the peacekeeping budget is grossly inadequate for the multitude of tasks that missions are expected to perform. ${ }^{18}$ The human rights component of the mandate tends to receive a minuscule share of the budget.

\section{Uncertain Political Commitment and Support}

In moral and normative terms, it is tempting to assume a high degree of political support and commitment to the protection of civilians and human rights in peacekeeping. Yet weak political support is the norm. This is partly a function of the way the protection mandate has developed, but it is also a reflection of the general ambivalence at the global level about human rights, sovereignty, and the scope of international action.

Within the UN Security Council, where the peacekeeping mandate is defined, there are manifest misgivings about the human rights and protection undertaking. 
Members tend to have different understandings and expectations about individual peacekeeping operations and consensus on the scope of mandates is rare. While, in principle, each mission is supposed to be established after careful analysis and deliberations, that is atypical. Instead, the process is often a "cut and paste" job, with some political "give and take" and minimal deliberation on how the mandate is to be executed. It is left up to the secretariat at implementation to confront the difficult challenge of allocating scarce resources to competing tasks. This results in obfuscation and fruitless debate.

The trend toward partnership and subsidiarity is another dimension of the political challenge. The African Union and its RECs have increasingly assumed greater roles on peace and security matters in the region, including in peacekeeping. This is justified as a necessary complement to the UN's primary role and arguably a more effective approach to conflict resolution because of the proximity of regional organizations to the issues. But it belies a conceptual gap because regional organizations do not necessarily share the same normative perspectives. There is still a lot of reticence about human rights in the AU. Traditional sovereignty still predominates and poses a major obstacle to the realization of consensus on mass atrocities and other challenges emanating from human rights violations. This discordance between global and regional perspectives is a significant obstacle to the human rights agenda.

Political expediency also often overrides human rights niceties. In 2010 the UN shelved a comprehensive report about human rights violations in the DRC because of protests from some of the countries implicated in the report. A year earlier, a Security Council-appointed team opted not to discuss serious concerns about the integration of armed groups into the national army (FARDC), contrary to the UN Human Rights Due Diligence Policy, allegedly because it would upset the host government. On several occasions in South Sudan, sanctions for human rights violations were not pursued because of concern that they might jeopardize efforts to end the conflict.

Despite the huge scale of human rights violations in parts of Africa, the high level of political commitment which characterized past international engagements on human rights concerns in conflict elsewhere, such as Kosovo beginning in 1999, has not been evident. To put it bluntly, Africa tends to attract less attention. This could be a legacy of "conflict fatigue" over Africa or/and the absence of strong political interests on 
the continent among the key powers. It is argued by some that the international community lacks a genuine commitment to resolve conflicts in Africa; peacekeeping thus serves as a kind of palliative. The situation is not helped by an insidious paradox: those who fund peacekeeping, largely Western nations, define the mandate, which typically centers on damage limitation rather than substantive attempts to resolve the conflict; the Troop Contributing Countries (TCCs), which are largely from Africa and Asia, have little say in how the mandate is shaped. ${ }^{19}$

As the HIPPO report has pointed out, peacekeeping operations express "different interests and concerns"-of the Security Council, regional neighbors, and TCCs. It is therefore important to have "a shared understanding of the situation, a common political goal and clarity on the level of resolve and resources required to help deliver and sustain a political solution." ${ }^{20}$ The lack of political commitment and coherent support is serious and foreshadows most of the other challenges related to the mandate to protect civilians, including the lack of clarity on its scope, the diffusion of tasks and responsibilities, the limited resources and the lack of political support during critical phases of implementation.

\section{Conceptual Ambiguity}

Closely linked to the lack of political consensus is the fact that despite the overwhelming sentiment that the UN should do something about the plight of civilians in conflict, the key concepts-protection of civilians, human rights promotion and protection, humanitarianism and responsibility to protect-are used in different and sometimes contradictory contexts. These ambiguities lead to confusion, undermine political support, and negatively impact operationalization and implementation. ${ }^{21}$ For example, the UN Security Council has used the concept of "protection of civilians" in different senses, alluding to "physical protection" but also appearing to allow for other broader perspectives including human rights. In Resolution 2448, renewing MINUSCA's mandate, for example, the Security Council authorized it to "protect, without prejudice to the primary responsibility of the CAR Authorities and the basic principles of peacekeeping, the civilian population under threat of physical violence."22 This is essentially the same formulation that the Council has used since 1999 when it first mandated the protection of civilians in UNAMSIL, with minor but important modifications: deleting the phrase "imminent threat of violence" in earlier resolutions in favor of simply "threat of 
violence" apparently because the term "imminent" caused confusion and equivocation.

The formulation in the Security Council resolutions, particularly the use of terms such as "all necessary means," "civilians under threat," and "within area of operation or presence," and the context of the debate around the first mandate have been interpreted to suggest that the Security Council means "physical protection" when it mandates the protection of civilians. ${ }^{23}$ But the Security Council does not explicitly say that. Moreover, the language in other parts of the resolutions alludes to broader notions beyond physical protection. The standard caveats used in the resolutions-"consistent with principles of peacekeeping," "within their capabilities and areas of deployment"-seem to limit the scope of the mandate and create further confusion and uncertainty, seemingly permitting a peacekeeping mission to not act if it determines that it lacks the "capability." This may seem reasonable on the surface, but it creates the potential for equivocation, and no assurances that the mission will be held accountable for not acting.

In a bid to offer guidance to peace missions, the UN Department of Peacekeeping Operations (DPKO) has developed a policy aimed at clarifying and reconciling the concept. ${ }^{24}$ Supposedly, the policy draws from the Security Council's definition of "protection," 25 from which it elaborates three tiers of activities that encompass the protection of civilians. Tier I includes public information campaigns to promote respect for human rights; dialogue with a perpetrator or potential perpetrator to deter violations; mediation and the resolution of conflicts among the parties to the conflict; persuading governments and other relevant actors to intervene to protect civilians; and other related activities which are intended to prevent human rights violations. Tier II relates to physical protection and involves the show of or use of force by the police and military components to prevent, deter, preempt, or respond to situations in which civilians are under threat of physical violence. Tier III are activities that are intended to create an environment that protects civilians, such as supporting elections and political processes; conflict mediation and resolution; security sector reform; strengthening the rule of law; the promotion and protection of human rights; the disarmament, demobilization, and reintegration of excombatants; and supporting the return and reintegration of IDPs and refugees. These are medium- to long-term programmatic activities of the entire UN system and partners in the country, including the peacekeeping mission. 
Complicating matters is the fact that human rights activists and groups, which play critical roles in the protection of civilians, often have different perspectives. The humanitarian community envisages the protection of civilians to include "all efforts aimed at obtaining full respect for the rights of the individual and of the obligations of the authorities/arms bearers in accordance with the letter and the spirit of the relevant bodies of law." 26 From a human rights perspective, the scope of protection is much broader, covering all the rights and freedoms recognized in international and regional instruments and ensuing obligations, including international human rights law, international humanitarian law, international criminal law, and international refugee law, and applies in times of peace and war to all individuals, not just civilians. ${ }^{27}$ The DPKO policy seems to embrace both the humanitarian and human rights perspectives.

It is left up to peacekeeping missions to develop their strategy for the protection of civilians, indicating priority areas of focus. This may seem pragmatic but it is not prudent. Mission strategies tend to be a laundry list: clearly articulated, concrete goals and priorities are absent. The differing and sometimes competing perspectives on the key concepts has made it challenging to articulate "protection of civilians" in implementable terms. ${ }^{28}$ There is no consensus in the Security Council on when it should be triggered and what the circumstances warrant. The various components in UN peacekeeping missions can become embroiled in disagreements over concepts, which impede the development of a decisive, unified approach. Humanitarian partners, for instance, eschew the carrying of or use of arms for physical protection. This can create tension with, as well as uncertainty and indecision for, the military component (and TCCs). The consequent inaction is then exploited by the host country and those not fully supportive of human rights and the protection of civilians.

\section{COMPATIBILITY WiTh THE ORIGINAL IDEA OF PEACEKEEPING}

Although it is generally conceded that UN peacekeeping has evolved from its traditional underpinnings, its original architecture remains in place. The idea behind UN peacekeeping was to position "neutral" UN troops between belligerents who had agreed to stop fighting in order to limit the risk of resumption in the fighting while a peace process was progressing. ${ }^{29}$ It was considered a limited instrument, premised on a peace agreement 
and the commitment of the parties, and the UN as a peace broker and a neutral party with no stake in the conflict. The core UN peacekeeping principles-impartiality, consent, and the restriction on the use of forcederive from this general context and premises. ${ }^{30}$

Much of the original conception no longer holds. And yet, it continues to dominate the architecture of peacekeeping. As African experiences demonstrate, UN peacekeeping is no longer just deployed where fighting has ended; in fact, it is usually deployed where active hostility is still on-going, often involving multiple actors. Furthermore, the typical peacekeeping mandate today is also expansive, comprising mediation, extending and supporting state authority, and protecting civilians, sometimes against their own governments.

\section{Finding the Right Balance Among the Tools}

An important policy issue that has not received much attention concerns the order of priorities among the various peacebuilding tools. The relationship between the relative investments in physical protection and diplomatic engagement is a case in point. In practice, military and police components receive far greater resources and attention than the political aspects. Yet it is the politics on which so much else, including the physical, turns. $^{31}$

Physical protection, in the sense outlined in Tier II of the DPKO Policy, involving “...those activities by police and military components involving the show or use of force to prevent, deter, pre-empt and respond to situations in which civilians are under threat of physical violence" 32 is important and necessary as a protection tool. It is this idea which dominates the Security Council's thinking when it mandates the protection of civilians. Peacekeeping missions need a force not only to protect the mission's assets and personnel but also, as recommended in the Brahimi report, "to protect civilians in imminent risk of violence." Hence, the trend toward enforcement mandates and the robust initiatives such as the Force Intervention Brigade (FIB) within the United Nations Organization Stabilization Mission in the Democratic Republic of the Congo (MONUSCO), which was mandated to carry out "targeted offensive operations" to "neutralize armed groups" 33 and the Regional Protection Force in UNMISS.

Heads of missions and TCCs regularly complain that they lack the resources to properly equip the military and police for the mandated tasks, 
especially for its physical protection responsibility. As Hilde Johnson has pointed out, the glaring mismatch between the UNMISS' mandate and its resources made it "close to impossible" for the mission to deliver on its mandate to provide physical protection to civilians under threat. ${ }^{34}$ Objective assessments confirm that almost all are woefully equipped for the challenge that they confront. On the other hand, the military and police components consume the bulk of the resources of the mission. They are expensive. The civilian components of peacekeeping missions receive very little in relative terms, and most of their resources are allocated to staff salaries and benefits. Very little, if any, is devoted to programs.

The argument is not that the allocation for the military and police should be reduced. On the contrary, there is a very good case to be made that they ought to be properly equipped and staffed to meet the requirements of the mandated tasks. But in the current scenario, where the military are inadequately equipped and there is under-investment in the diplomatic and political spheres, success is all but impossible. Along with strengthening the military component, therefore, it will be important to invest commensurately in the diplomatic and political dimensions, and to strengthen more explicit synergy among the three. Clarity is also needed on the relevance of the peacekeeping principles, especially consent and the use of force.

\section{Enforcing the Primary Responsibility of the Host State}

Under international law, the state bears the primary responsibility to protect human rights. This is concretized in the "Responsibility to Protect" doctrine: the idea that sovereignty entails the responsibility to protect, which came out of the same movement and sentiment that spurred the protection of civilians mandate in UN peacekeeping. The state's responsibility entails the duty to ensure that its institutions and citizens, and those under its control, do not violate human rights.

All Security Council resolutions mandate peacekeeping operations to protect civilians "without prejudice to the responsibility of the state." In practice, the state is best placed to protect human rights. As HIPPO rightly points out, however, peacekeeping, even in ideal circumstances, is no substitute for an effective state. ${ }^{35}$ A necessary part of a strategy for the protection of civilians should be to ensure the state fulfills its primary responsibility. 
In most peacekeeping situations, the state is either unable to provide protection or often complicit in, if not responsible for, perpetrating human rights violations and undermining the rule of law. In South Sudan, for example, the state is implicated in violent attacks against civilians; in CAR, some of the armed groups that are accused of human rights violations are supported by the state. In these circumstances, the responsibility of the international community is to remind the state of its responsibility and to support the state as necessary to enable it to fulfill its responsibility; failing that, the international community must intervene through diplomatic demarches or even armed intervention.

UN peacekeeping missions have not been very effective in holding the state to its primary responsibility-using any of these tools-and do not consistently use their political leverage. The failure to act has had the impact of emboldening governments and other perpetrators, perpetuating impunity and possibly worsening the human rights situation. The most intransigent countries, such as the DRC and South Sudan, ignore Security Council resolutions and ultimatums because they are confident that there will be no repercussions. In turn, this tends to disempower and undermine the peacekeeping mission's human rights efforts. Cognizant that they are unlikely to get strong support from the Security Council and from the UN, mission leadership treads very carefully around human rights issues.

\section{Key Recommendations}

\section{Reinvigorate UN peacekeeping focus on the protection of civilians} and buman rights. Without this, its core mission of ending conflict and restoring peace and stability is unlikely to succeed. Despite some notable accomplishments, overall the UN's record on the protection of civilians and human rights is poor. Mandates have almost invariably promised more than they have delivered. There are far too many reports of civilians being attacked, sometimes in the presence of UN peacekeepers, and cases where the system has not responded adequately or failed to respond in the face of threats to civilians. Reviews of UN peacekeeping performance identify formidable challenges: weak and unreliable political support; conceptual and normative ambiguities; differing interpretations by key actors on the scope of the mandate; structural and systemic contradictions, and inadequate resources and capabilities. 
What is clear from this record is that the current state of affairs is no longer tenable. UN peacekeeping must move beyond rhetoric and improve its performance. A genuine commitment to implement the recommendations of HIPPO, which member states seem to support, would be an important first step.

2. Strengthen political consensus around human rights and the protection of civilians. The assumption that the fundamentals of peacekeeping and protection of civilians are sound is false. Equivocation, politicization, and a weak consensus persist around critical issues. It is therefore important to have an honest debate to seek fresh consensus on the purpose, relevance, and scope of the protection of civilians mandate and its place in peacekeeping, including a realistic assessment of what peacekeeping can-and cannot-deliver. ${ }^{36}$ That will not be easy in the context of the current erosion of the international global order, but the issue must be addressed more candidly for meaningful change to take place in a process involving all key actors-General Assembly member states, regional groups and neighbors, TCCs, etc.-in order to close the gap between the Security Council where mandates are defined and the other actors who bear some of the responsibility for implementation.

3. Address the apparent incompatibility between traditional peacekeeping and deference to national sovereignty. The apparent incompatibility between the traditional principles of peacekeeping, particularly with respect to the requirement for consent and the underlying deference to sovereignty, and what is required to protect human rights needs to be resolved. The obstinacy of the host state, in delaying requests for patrols, restricting the movement of peacekeepers and visits to sites of human rights violations, perpetually frustrate efforts to protect civilians and are indefensible. Waiting for consent in such circumstances undermines the protection of civilians. The privilege of sovereignty does not seem warranted in such cases. On the contrary, a more concerted effort is needed to uphold and enforce the primary responsibility of the host state to defend and protect human rights. Peacekeeping can only do so much and will not succeed without this. The Security Council needs to demonstrate that it has the resolve to follow through. Moreover, that it will take action if its resolutions are not respected or cooperation is absent. Strongly worded resolutions and threats are not enough and 
could even be damaging to international order and the credibility of the Security Council if they can be ignored with impunity.

4. Close the gap between mission mandates and resources required to achieve the missions. As others have recommended, the Security Council needs to more seriously consider the operational implications of mandates and the resources and other capabilities required to follow through and implement the mandate; doing more with less is a failing strategy. UN missions should be properly staffed and equipped and a more explicit link between the military, political and diplomatic aspects of the mandate should be cultivated. The UNSC should also continue to be involved at all stages of the mandate's implementation and, in particular, to continue to lend political support, including to heads of missions, who must be accountable. The Security Council should approach subsidiarity with caution, remain closely engaged and insist on adherence to agreed international norms - to deter regional organizations and neighbors from acting as spoilers, as they sometimes do.

\section{Notes}

1. United Nations, Uniting our Strengths for Peace, Politics, Partnerships and People, Report of the High-Level Independent Panel on United Nations Peace Operations, A/70/95-S/2015/446 (June 17, 2015), 9 (HIPPO).

2. Ibid., para 80 (protection of civilians in armed conflict is a core principle of international humanitarian law and a moral responsibility for the United Nations).

3. There have been more than 50 peace operations in Africa in the twentyfirst century as Williams points out, but not all of them are UN-led. See Paul D. Williams, War and Conflict in Africa, 2nd ed. (Malden, MA: Polity, 2016), 279-281.

4. See, e.g., the most recent statement by the President of the Security Council, May 14, 2018, S/PRST/2018/10, reiterating that peacekeeping complements the UN's peace and security strategy and affirming the Security Council's commitment to the protection of civilians.

5. United Nations, Report of the Secretary-General Pursuant to General Assembly Resolution 53/35: The Fall of Srebrenica, A/54/549 (November 15, 1999), para 49; and United Nations, Report of the Independent Inquiry into the Actions of the United Nations during the 1994 Genocide in Rwanda, S/1999/1257 (December 16, 1999), paras. 50-52.

6. United Nations, Report of the Panel on United Nations Peace Operations (the Brabimi Report), A/55/305 (2000) and S/2000/809. 
7. United Nations, Report of the Secretary-General to the Security Council on the Protection of Civilians in Armed Conflict (1999).

8. Piers Robinson, The CNN Effect: The Myth of News, Foreign Policy and Intervention (London and New York: Routledge, 2002).

9. Haidi Wilmont, Ralph Mamiya, Scott Sheeron, and Marc Weller (eds.), Protection of Civilians, lst ed. (Oxford University Press, 2016). Protection of civilians existed since the beginning of the UN although it was not explicitly mandated.

10. The only UN peacekeeping operation deployed since 1999 without a protection of civilians mandate was the UN Supervision Mission in Syria (UNSMIS). See SC Res. 2043 (April 14, 2012), https://www.securi tycouncilreport.org/atf/cf/\%7b65BFCF9B-6D27-4E9C-8CD3-CF6E4F F96FF9\%7d/Syria\%20SRES\%202043.pdf.

11. For an overview of the protection of civilians mandate in UN Peacekeeping, see generally Victoria Holt and Glyn Taylor with Max Kelly, "Protecting Civilians in the Context of UN Peacekeeping Operations, Successes, Setbacks and Remaining Challenges," Independent Study Jointly commissioned by the Department of Peacekeeping Operations and the Office for the Coordination of Humanitarian Affairs (2009), Chapter 2, 33-88, https://www.unocha.org/sites/dms/Documents/Pro tecting $\% 20$ Civilians $\% 20 \mathrm{in} \% 20$ the $\% 20$ Context $\% 20$ of $\% 20$ UN\%20Peaceke eping\%20Operations.pdf; For a list of current peacekeeping operations, see https://peacekeeping.un.org/en/where-we-operate and for a timeline of Peacekeeping Operations, see https://peacekeeping.un.org/en/ past-peacekeeping-operations.

12. HIPPO.

13. Harvard Hegre, Lisa Hultman, and Havard Mokleiv Nygard, "Peacekeeping Works: An Assessment of the Effectiveness of UN Peacekeeping Operations," Conflict Trends 1 (2015), https://www.prio.org/utility/ DownloadFile. ashx?id=96\&type $=$ publicationfile.

14. Lisa Hultman, Jacob Kathman, and Megan Shannon, "United Nations Peacekeeping and Civilian Protection in Civil War," American Journal of Political Science 57, no. 4 (2013): 875-891; and Alexandra Novosseloff, “Can We Make Peacekeeping Great Again?" Global Peace Operations Review (May 9, 2017). "UN peace operations are helping to protect thousands of civilians on a daily basis through monitoring and advocacy of human rights, supporting the development of the rule of law, and political engagement with the conflict parties, as well as through physical presence, deterrence and protective action."

15. E.g., Séverine Autesserre, "Crisis of Peacekeeping: Why the UN Can't End Wars," Foreign Affairs (January/February 2019).

16. See Paul D. Williams, Chapter 2 on "Learning Lessons from Peace Operations in Africa" in this book. 
17. Both the Brahimi (UN doc. A/55/305-S/2000/809, August 21, 2000) and the HIPPO reports (UN doc. A/70/95-S/2015/446, June 17, 2015 ) acknowledged 15 years later the serious impact of overcrowded mandates and urged realistic prioritization.

18. Hilde Johnson, "Capacity to Protect Civilians: Rhetoric or Reality?” International Forum for the Challenges of Peace Operations, Policy Brief 2015:4. Introduction: Protection of Civilians Norms and Frameworks

19. Autesserre, "Crisis of Peacekeeping."

20. HIPPO, para 58.

21. Betrand Ramcharan (ed.), Human Rights Protection in the Field (London: Routledge, 2006), 102. The lack of a "common, system-wide ... understanding of the concept of 'protection' has given rise to problematic inconsistencies in both usage and practice."

22. Similar language was used in the initial resolution which established the United Nations Multidimensional Integrated Stabilization Mission in the Central African Republic (MINUSCA) (Res. 2149) which mandated it to "protect, without prejudice to the primary responsibility of the Central African Republic authorities, the civilian population from threat of physical violence, within its capabilities and areas of deployment, including through active patrolling."

23. Wilmont, Mamiya, Sheeron, and Weller, Protection of Civilians, 97. The language and the discussion surrounding the first adoption of the protection of civilians mandate indicate that the Security Council conceived the protection of civilians narrowly in terms of physical protection from the threat of imminent violence.

24. United Nations, Policy on Protection of Civilians, S/RES/2382 (2017). An update of the first version developed in 2010 after recommendation for UN system wide guidelines in OCHA/DPKO study.

25. "all necessary means, up to and including the use of deadly force, aimed at preventing or responding to threats of physical violence against civilians, within capabilities and areas of operations, and without prejudice to the responsibility of the host government."

26. Inter-Agency Standing Committee, "Policy on Protection in Humanitarian Action" (2016), https://interagencystandingcommittee.org/pro tection-priority-global-protection-cluster/documents/iasc-policy-protec tion-humanitarian-action.

27. UN Human Rights Council, Protection of the Human Rights of Civilians in Armed Conflict, Res. 9/9, 2008; Statement of Navi Pillay, UN High Commissioner for Human Rights, at the UN Security Council Debate on the Protection of Civilians in Armed Conflict (June 25, 2012) https://newsarchive.ohchr.org/EN/NewsEvents/Pages/Dis playNews.aspx?NewsID=12288; and $\mathrm{OHCHR}$ staff, "Protection in the 
Field: Human Rights Perspectives," in Human Rights Protection in the Field, Betrand Ramcharan (ed.) (London: Routledge, 2006), 119, 121.

28. Ramcharan, Human Rights Protection in the Field.

29. Wilmont, Mamiya, Sheeron, and Weller, Protection of Civilians. Missions such as UNTSO (Jerusalem); UNMOGP (Kashmir); UNFCIYP (Cyprus); UNDOF (Golan Heights); UNIFIL (South Lebanon); MINURSO (Western Sahara); and UNISFA (Abyei) represent this notion of peacekeeping.

30. United Nations Department of Peacekeeping Operations, United Nations Peacekeeping Operations: Principles and Guidelines, Principles of UN Peacekeeping (2008), https://peacekeeping.un.org/sites/default/files/ peacekeeping/en/capstone_eng.pdf.

31. HIPPO, para 107. Lasting peace is not achieved or sustained by military and technical engagements, but through political solutions- - "political solutions, not military force, are the true force multipliers' for peacekeepers."

32. See http://civilianprotection.rw/wp-content/uploads/2015/05/201507-Policy-on-PoC-in-Peacekeeping-Operations.pdf.

33. United Nations, The Situation in Democratic Republic of the Congo, UNSCR 2098 (March 28, 2013), para 12b.

34. Johnson, "Capacity to Protect Civilians."

35. HIPPO, para 27.

36. HIPPO, para 41, urges consensus on the future direction and needs of UN peace operations to be restored, and a genuine collaboration and commitment by the General Assembly and Security Council to go "beyond the diplomatic trench lines of the last decade and to find solutions on how best to deal with today's threats and how to strengthen United Nations peace operations for tomorrow. This will require a spirit of genuine collaboration and inclusion so as to establish a common purpose and resolve." 
Open Access This chapter is licensed under the terms of the Creative Commons Attribution 4.0 International License (http://creativecommons.org/licenses/ by $/ 4.0 /$ ), which permits use, sharing, adaptation, distribution and reproduction in any medium or format, as long as you give appropriate credit to the original author(s) and the source, provide a link to the Creative Commons license and indicate if changes were made.

The images or other third party material in this chapter are included in the chapter's Creative Commons license, unless indicated otherwise in a credit line to the material. If material is not included in the chapter's Creative Commons license and your intended use is not permitted by statutory regulation or exceeds the permitted use, you will need to obtain permission directly from the copyright holder.

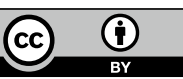

